\title{
THE NATURE OF PLASMA AND URINARY PROTEINS IN NEPHROSIS
}

\author{
By ALF S. ALVING AND A. E. MIRSKY \\ (From the Hospital of the Rockefeller Institute for Medical Research, New York City)
}

(Received for publication December 7, 1935)

In the types of Bright's disease exhibiting the nephrotic syndrome, in which large quantities of albumin are excreted in the urine and the concentration of albumin in the plasma is lower than normal, the question arises as to whether the chemical constitution of this albumin is the same as that of normal albumin. When one considers that in this condition it is not unusual for the body to produce and excrete as much as 20 grams of albumin a day, it may well be that some ingredient of normal albumin is not available in sufficient amounts for the elaboration of 20 grams of normal albumin and that consequently an albumin of abnormal constitution is produced.

To characterize the proteins of plasma and urine we have estimated their cystine content. We chose cystine for this purpose rather than some other amino acid because cystine is present in serum albumin in much higher concentration than it is in most other proteins. The cystine concentration of recrystallized serum albumin of the horse is 6.06 per cent $(6,13)$ while that of the serum globulins is 2.2 per cent, of casein 0.3 per cent (11), proteins of meat 0.8 per cent (13), proteins of fish 1.2 per cent (13), edestin 1.0 per cent (12). Of the common proteins only those of hair. and skin are known to have a higher cystine content than has albumin. A further advantage of characterizing albumin by its cystine content is that the methods of estimating cystine appear to be trustworthy. The method of Folin and Marenzi (6) is reliable except when applied to a protein which contains cysteine as well as cystine (10). Since serum albumin contains no cysteine, analysis of its cystine content by the Folin-Marenzi method is accurate; we have, therefore, used this method.

\section{Preparation of protein for analysis}

From blood. Albumin was prepared from 150 to $200 \mathrm{cc}$. of heparinized or oxalated blood by centrifuging and adding to the separated plasma an equal volume of saturated $\left(\mathrm{NH}_{4}\right)_{2} \mathrm{SO}_{4}$. Af- ter standing overnight the precipitated fibrinogen and globulin were removed by filtration, the filtrate was diluted with about 3 volumes of water, and the albumin therein precipitated by adding to this solution $1 / 10$ its volume of 50 per cent $\mathrm{CCl}_{3} \mathrm{COOH}$ solution. The albumin was recovered from this suspension by centrifuging, the protein-free supernatant fluid being discarded. To remove $\left(\mathrm{NH}_{4}\right)_{2} \mathrm{SO}_{4}$ from the albumin precipitate, the latter was stirred in a $250 \mathrm{cc}$. centrifuge flask with $200 \mathrm{cc}$. of water and then reprecipitated by adding $20 \mathrm{cc}$. of 50 per cent $\mathrm{CCl}_{3} \mathrm{COOH}$ solution. The serum albumin precipitate was washed in this way 4 or 5 times. To free the albumin of $\mathrm{CCl}_{3} \mathrm{COOH}$ the precipitate was transferred to a $35 \mathrm{cc}$. collodion tube and dialyzed against $0.01 \mathrm{~N}$ $\mathrm{HCl}$ for about 12 hours in a rocking dialyzer. To obtain the protein in the form of a dry powder the dialysate was added to 10 times its volume of acid acetone ( $1 \mathrm{cc}$. of $1.0 \mathrm{~N} \mathrm{HCl}$ in $100 \mathrm{cc}$. acetone), and the precipitated albumin recovered by centrifuging. The albumin was further dehydrated by stirring with about $200 \mathrm{cc}$. of acid acetone, the bulk of the acetone was removed by centrifuging, and still more was drawn off by suction until the albumin had the consistency of a thick paste. It was then transferred to a hot mortar, ground to a dry powder and placed in an oven at $100^{\circ} \mathrm{C}$., where 1 hour sufficed for drying to constant weight. The albumin was now ready to be weighed and analyzed.

Since the lipoid concentration was very high in the plasmas from which most of the albumin samples were prepared, it was necessary to ascertain to what extent the albumin preparations were contaminated with lipoid. Nitrogen estimations of the albumins prepared from two plasmas, one of which was obtained from a patient (Case 2) and contained an abnormally high concentration of lipoids, whereas the other was from a normal person, showed that the percentage of nitrogen was about the same in both ( 14.3 and 15.0 per cent, respectively); we regarded this result as evi- 
ALF S. ALVING AND A. E. MIRSKY

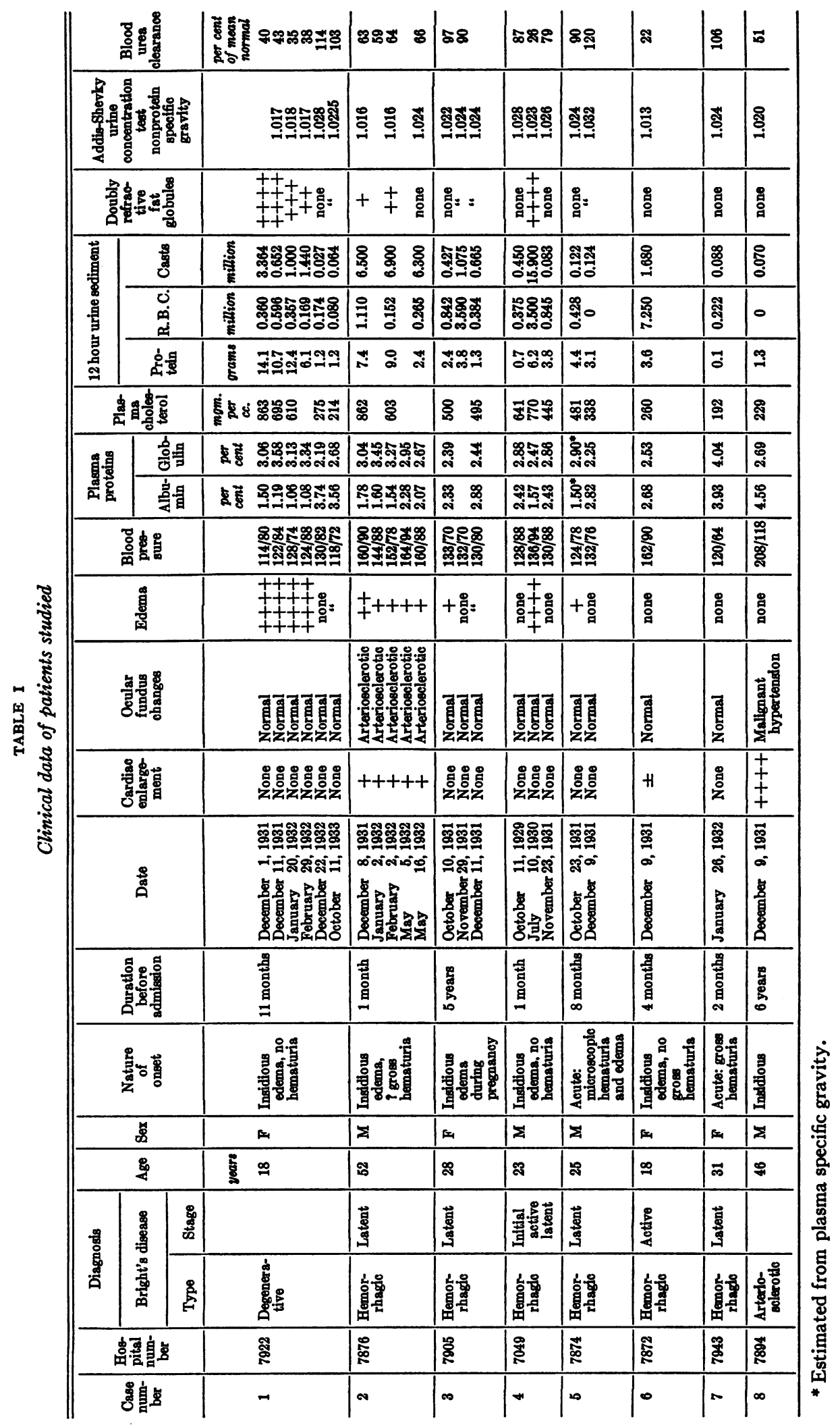


dence that the albumin prepared from plasma rich in lipoids was not unduly contaminated by lipoid.

From urine. After the urine was neutralized with $\mathrm{N} / 10 \mathrm{NaOH}$, using phenol red as indicator, the preparation of albumin was substantially as described above.

\section{Cases studied}

Eight patients with Bright's disease and five normal subjects were studied. The clinical observations and tests are summarized in Table I, wherein the Addis classification (1) is followed. The first patient fulfilled all the criteria usually regarded as necessary for the diagnosis of "genuine or pure lipoid nephrosis" (9) if it is granted that moderate temporary diminution of renal function can occur in this condition. The second patient was observed during the nephrotic stage of glomerulonephritis. Cases 3 to 6 inclusive all had passed through a nephrotic stage during the course of glomerulonephritis but at the time the character of the proteins in their blood was studied they were edema free and the proteins in the plasma, though lower than normal, had risen above the concentration ordinarly characterized by edema. The other two patients had no nephrotic symptoms.

TABLE II

Cystine content of albumin

\begin{tabular}{|c|c|c|c|c|c|}
\hline $\begin{array}{c}\text { Case } \\
\text { num- } \\
\text { ber }\end{array}$ & Date & $\begin{array}{l}\text { Plasma } \\
\text { albumin } \\
\text { concen- } \\
\text { tration }\end{array}$ & $\begin{array}{l}\text { Cystine } \\
\text { content of } \\
\text { plasms } \\
\text { albumin } \\
\text { fraction }\end{array}$ & $\begin{array}{l}12 \text { hour } \\
\text { excretion of } \\
\text { protein in } \\
\text { urine }\end{array}$ & $\begin{array}{l}\text { Cystine } \\
\text { concentra- } \\
\text { tion of } \\
\text { urinary } \\
\text { albumin }\end{array}$ \\
\hline & & $\begin{array}{l}\text { grams per } \\
100 \text { ce. }\end{array}$ & per cent & grame & per cont \\
\hline 1 & $\begin{array}{l}\text { December } 1,1931 \\
\text { January } \\
20,1932 \\
\text { October } \\
13,1933\end{array}$ & $\begin{array}{l}1.5 \\
1.06 \\
3.56\end{array}$ & $\begin{array}{l}2.19 \\
2.33 \\
5.20\end{array}$ & $\begin{array}{r}14.1 \\
12.4 \\
1.2\end{array}$ & $\begin{array}{l}8.25 \\
3.39\end{array}$ \\
\hline 2 & December 8,1931 & 1.78 & 8.03 & 7.4 & 3.49 \\
\hline 3 & December 8. 1931 & 2.88 & 4.60 & 1.3 & 4.42 \\
\hline 4 & $\begin{array}{l}\text { November 24, } 1931 \\
\text { January } 26,1932\end{array}$ & $\begin{array}{l}2.43 \\
2.45\end{array}$ & $\begin{array}{l}3.55 \\
3.63\end{array}$ & & \\
\hline 5 & December 9,1931 & 2.82 & $\mathbf{3 . 9 0}$ & & \\
\hline 6 & December 9, 1931 & 2.68 & 3.46 & & \\
\hline 7 & Janiuary 26, 1932 & 3.93 & 3.96 & & \\
\hline 8 & December 9. 1931 & 4.56 & 4.31 & & \\
\hline
\end{tabular}

RESULTS

In patients in whom the concentration of albumin in the plasma was low, the cystine content of the albumin fraction was lower than normal (Table II).

The cystine content of the urinary albumin varied with the cystine content of albumin in the plasma. When the latter was normal the urinary albumin had the same cystine content (as in Case 3), and when the cystine content of albumin in the plasma was less than normal, that of urinary albumin was also lower. It is noteworthy that the decrease in cystine content was, however, distinctly less in urinary albumin than it was in that of the plasma. The kidney appears to have fractionated the latter.

\section{Cause of the variations in cystine content of albumin in the plasma}

Are the differences in cystine content due to changes in constitution of the serum albumin molecules or to the presence of some other body with a low cystine content in the so-called albumin fraction? It may be thought that globulin has become included in the albumin fraction, possibly because of the abnormally high globulin: albumin ratio in the nephrotic syndrome. ${ }^{1}$ This is hardly possible for. in one instance (Case 1) the cystine content of the albumin (2.19 per cent) is as low as that of globulin itself (2.27 per cent). When globulin and albumin from normal plasma were mixed in the ratio obtaining in this disease, the albumin recovered from this mixture after halfsaturation with $\left(\mathrm{NH}_{4}\right)_{2} \mathrm{SO}_{4}$ had, furthermore, the cystine content characteristic of normal albumin.

A globulin albumin mixture of relatively high globulin content was prepared in the following manner: To 20 cc. of oxalated plasma were added 20 cc. saturated $\left(\mathrm{NH}_{4}\right)_{2} \mathrm{SO}_{4}$, and the mixture filtered through hardened paper. The globulin on the paper was washed in halfsaturated $\left(\mathrm{NH}_{4}\right)_{2} \mathrm{SO}_{4}$ solution until the washings yielded no precipitate on addition of concentrated trichloracetic acid. The globulin was scraped off the paper, transferred to a $15 \mathrm{cc}$. collodion tube which was filled with an 0.8 per cent $\mathrm{NaCl}$ solution and placed in a rocking dialyzer where for 12 hours it was dialyzed against an 0.8 per cent $\mathrm{NaCl}$ solution. The dialyzed globulin was brought to a volume of $20 \mathrm{cc}$. by addition of saline and then mixed with $10 \mathrm{cc}$. of the original plasma.

The possibility remains that some substance other than globulin is mixed with serum albumin

1 Whereas the ratio of albumin to globulin is normally about 2 to 1 , in nephrosis it may be less than 1 to 2 . 
in the albumin fraction and it has, in fact, been possible to separate the albumin fraction (of Case 2) into two parts. Separation was effected by dialyzing against distilled water; part of the protein of the albumin fraction remained in solution while the rest precipitated. That part remaining in solution was found to contain cystine in an amount equal to that of normal albumin (4.44 per cent) whereas the precipitated portion contained only about $1 / 10$ th as much (approximately 0.5 ).

The solution of albumin in half-saturated $\left(\mathrm{NH}_{4}\right)_{2} \mathrm{SO}_{4}$ was dialyzed against distilled water for 24 hours in a rocking dialyzer. The precipitate, which had gradually appeared, was separated by centrifuging and was then thoroughly washed with water. The precipitated protein and the protein which remained in solution after dialysis were both dried after dehydrating in acid acetone.

The precipitate formed during dialysis appears to be of protein nature because its nitrogen content (as estimated by $\mathrm{Kjeldahl}$ analysis) is 14.0 per cent (Case 1). The small amount so far available has prevented an investigation of its properties. Its low cystine content (if the cystine found in it is indeed not due to the presence of a trace of serum albumin) suggests that this new substance is not a fraction of serum globulin. Since some globulin fraction may, however, have a cystine content much lower than that of mixed globulin, the latter. was separated into eu- and pseudoglobulin and the cystine content of each was estimated. The analyses indicated that the new substance is not a globulin fraction, for the cystine content of both eu- and pseudoglobulin we find to be 2.2 per cent.

The question now arises as to whether this substance occurring in the albumin fraction is a normal hitherto unrecognized constituent of plasma present in nephrosis in relatively high concentration or whether its existence is peculiar to nephrosis. There are some indications that this substance may be a constituent of normal plasma. In experiments on the cystine content of the serum albumin of horses it has been found that although the cystine content of albumin which has several times been recrystallized is about 6 per cent, that of the whole albumin fraction is only 4.5 per cent. It appears, therefore, that during crystallization some substance with a relatively low cystine content was removed. The possibility must be con- sidered that this substance is the same as the one we have encountered in nephrosis, there made conspicuous by the relatively low concentration of albumin.

\section{DISCUSSION}

It is now necessary to collate our results with those of others. Some investigators, after greatly purifying the protein fractions, have reported that the serum and urinary proteins of patients exhibiting the nephrotic syndrome have properties indistinguishable from the serum proteins of normal individuals. Hewitt $(7,8)$ could not differentiate the urinary albumin from normal serum albumin by the specific rotatory powers, refractive indices, or the ultraviolet absorption spectra. Widdowson (17) found the urinary and serum proteins of patients having nephritis indistinguishable from normal serum proteins. Similar proteins of a patient suffering from nephrosis had slightly different nitrogen distributions, but their racemization curves, osmotic pressures, and specific refractions appeared to be identical with those of proteins from normal human serum.

Other investigators, not having fractionated or purified the proteins as greatly as the first group, have found differences. Though Cavett (3) and Cavett and Gibson (4) originally reported, after study of the nitrogen distributions and racemization curves of the urinary and plasma proteins of nephritic subjects, that these proteins are identical or very similar to normal serum proteins, Cavett (5) has since obtained one sample of urinary protein that seemed to have a different nitrogen distribution from that of blood protein. Tuchman and Sobotka (15) observed that the serum proteins of patients suffering from chronic glomerulonephritis contain abnormal proportions of tyrosine when the total concentration of the serum proteins is below 6 per cent.

Our results can be harmonized with both groups of investigators depending on whether we deal with the whole serum albumin fraction or one of its subfractions. The whole serum albumin fraction of patients exhibiting the nephrotic syndrome contains less cystine than normal serum albumin, but on further fractionation this albumin can be separated into two parts, one containing the same amount of cystine as normal serum albumin, the other containing less cystine than either normal 
serum albumin or globulin. The kidney appeared in the cases studied, to fractionate the whole serum albumin when the latter contained less cystine than normal so that the whole albumin fraction of the urine contained more cystine than the corresponding fraction in the blood but less than normal serum albumin.

As to the general significance of our work little can be said at present. The changes that we have observed occur in the "nephrotic stage" of chronic glomerulonephritis as well as in so-called pure "lipoid nephrosis." These two conditions, if indeed they are separate entities, cannot be differentiated by the amount of cystine contained in their urinary or serum proteins. We do not interpret our results as having a direct bearing on the cause of proteinuria in nephrosis.

After the experiments described in this paper were completed there appeared two papers on the cystine content of serum proteins, one by Tuchman and Reiner (16) and the other by Reiner and Sobotka (14). These authors used the method of Folin and Marenzi in a slightly modified form. The results they obtained for the proteins of normal sera were distinctly higher and more variable than those we find. Whereas we find globulin contains 2.2 per cent cystine they have reported values varying from 2.34 per cent to 4.70 per cent and averaging 3.64 per cent. A difference between our procedure and theirs is that we dry the proteins before hydrolysis and hydrolyze with $6 \mathrm{~N} \mathrm{H}_{2} \mathrm{SO}_{4}$ whereas they precipitated the proteins with trichloracetic acid, centrifuged, decanted the supernatant fluid and hydrolyzed with $14 \mathrm{~N} \mathrm{H}_{2} \mathrm{SO}_{4}$. Following their procedure we obtain, in agreement with them, a cystine content for globulin of 3.44 per cent. If globulin is hydrolyzed with $10 \mathrm{~N} \mathrm{H}_{2} \mathrm{SO}_{4}$ the cystine content is estimated to be 2.99 per cent. The cystine estimated, therefore, varies with the concentration of sulfuric acid used for hydrolysis. We find that when we precipitate serum with trichloracetic acid in the manner described by these authors, the final volume of the precipitated protein is approximately $0.6 \mathrm{cc}$. If for hydrolysis $2.5 \mathrm{cc}$. of $14 \mathrm{~N} \mathrm{H}_{2} \mathrm{SO}_{4}$ are used, the final concentration of $\mathrm{H}_{2} \mathrm{SO}_{4}$ is $11.3 \mathrm{~N}$, as compared with the $6 \mathrm{~N} \mathrm{H}_{2} \mathrm{SO}$, used by Folin and Marenzi. This modification of the FolinMarenzi method accounts for the high values obtained by Tuchman, Reiner and Sobotka, and it probably also accounts for the variability of their results, for it is unlikely that the concentration of $\mathrm{H}_{2} \mathrm{SO}_{4}$ used by them for hydrolysis was kept constant. The apparent increase in cystine content due to the action of concentrated $\mathrm{H}_{2} \mathrm{SO}_{4}$ is probably due to the conversion of methionine into homocystine, for Butz and du Vigneaud (2) have shown that this transformation occurs in the presence of concentrated $\mathrm{H}_{2} \mathrm{SO}_{4}$ and that homocystine reacts with the phosphotungstate of Folin and Marenzi.
Dr. M. X. Sullivan has kindly estimated the cystine content of a sample of serum globulin for which the value given by the Folin-Marenzi method is 2.2 per cent. The value he obtained by his method was 1.82 per cent and by the Okuda method was 1.92 per cent.

\section{SUM MARY}

1. The cystine content of the protein fraction remaining after precipitation of the globulins in the plasma of patients with the nephrotic syndrome is lower than the cystine content of normal serum albumin.

2. This protein fraction can be separated into two parts : one part appears to be the same as normal serum albumin, for it has the same cystine content; the other contains far less cystine than does serum albumin or any serum globulin fraction.

3. When the globulin in the urine of these patients is precipitated it is found that the cystine content of the remaining protein is higher than that of the corresponding fraction of plasma but lower than that of normal serum albumin. The substance with low cystine content, therefore, appears to pass through the nephrotic kidney less readily than does serum albumin.

\section{BIBLIOGRAPHY}

1. Addis, T., A clinical classification of Bright's diseases. J. A. M. A., 1925, 85, 163.

2. Butz, L. W., and du Vigneaud, V., The formation of a homologue of cystine by the decomposition of methionine with sulphuric acid. J. Biol. Chem., 1932, 99, 135.

3. Cavett, J. W., A comparison of blood proteins with those of nephritic urine and edema fluids. J. Biol. Chem. (Proc.), 1930, 87, xvi.

4. Cavett, J. W., and Gibson, R. B., A comparison of the racemization curves for urinary, edema fluid, and blood plasma proteins. J. Clin. Invest., 1931, $10,857$.

5. Cavett, J. W. Personal communication.

6. Folin, O., and Marenzi, A. D., An improved colorimetric method for the determination of cystine in proteins. J. Biol. Chem., 1929, 83, 103.

7. Hewitt, L. F., Identity of urinary albumin. Biochem. J., 1927, 21, 1109.

8. Hewitt, L. F., Urine proteins in nephrosis, pregnancy and myelomatosis. Lancet, 1929, 1, 66.

9. Leiter, L., Nephrosis. Medicine, 1931, 10, 135.

10. Mirsky, A. E., and Anson, M. L., Sulfhydryl and disulfide groups of proteins. I. Methods of estimation. J. Gen. Physiol., 1935, 18, 307. 
11. Sullivan, M. X., Studies on the biochemistry of sulphur. IV. The colorimetric estimation of cystine in casein by means of the beta-naphtho-quinone reaction. Pub. Health Rep., 1929, Supp. 78.

12. Sullivan, M. X., and Hess, W. C., Studies on the biochemistry of sulphur. VII. The cystine content of purified proteins. Pub. Health Rep., 1930, Supp. 86.

13. Sullivan, M. X., and Hess, W. C., Studies on the biochemistry of sulphur. $X$. The cystine content of meat and fish. Pub. Health Rep., 1931, Supp. 94.
14. Reiner, M., and Sobotka, H., Tyrosine and cystine. Content of serum proteins. J. Biol. Chem., 1933, 100, 779.

15. Tuchman, L. R., and Sobotka, H., A comparison of the $W u$ and Kjeldahl methods of serum protein determination. J. Biol. Chem., 1932, 98, 35.

16. Tuchman, L. R., and Reiner, M., The cystine content of human serum proteins. J. Biol. Chem., 1933, $100,775$.

17. Widdowson, E. M., A comparative investigation of urine- and serum-proteins in nephritis. Biochem. J., 1933, 27, 1321. 